\title{
Sodium Tanshinone IIA Sulfonate Promotes RSV Replication by Type I Interferon-Independent Mechanism in Vitro
}

\section{Zhixu Ye}

Guizhou Provincial People's Hospital

Xin Jin

Guizhou Provincial People's Hospital

Li Yang

Guizhou Provincial People's Hospital

Benli Yu

Guizhou Provincial People's Hospital

\section{Lujun Shang}

Guizhou Provincial People's Hospital

\section{Yuxia Cui}

Guizhou Provincial People's Hospital

\section{Li Fan}

Guizhou Provincial People's Hospital

\section{Liping Wang}

Guizhou Provincial People's Hospital

\section{Enmei Liu}

Chongqing Medical University Affiliated Children's Hospital

Fuxun Yu ( $\nabla$ yufuxun@126.com )

Guizhou Provincial People's Hospital https://orcid.org/0000-0001-8804-2755

\section{Research}

Keywords: Respiratory syncytial virus, Sodium tanshinone IIA sulfonate, A549 cells, Viral replication, Type I interferon

Posted Date: December 1st, 2020

DOl: https://doi.org/10.21203/rs.3.rs-114493/v1

License: (c) (1) This work is licensed under a Creative Commons Attribution 4.0 International License. Read Full License 


\section{Abstract}

\section{Background}

Respiratory syncytial virus (RSV) is a leading cause of viral respiratory tract infection in young children and elderly worldwide. Sodium tanshinone IIA sulfonate (STS) is reported to have antiviral effect on some viruses. However, the effect of STS on RSV replication is still unknown.

\section{Methods}

To investigate the effect of STS on RSV replication, RSV infected A549 cell model was first established and treated with different concentration of STS $(12.5 \unrhd 25 \rrbracket 50 \rrbracket 100$ and $200 \mu \mathrm{g} / \mathrm{ml})$.CPE, virus titer and RSV $\mathrm{N}$ protein were detected. Cytotoxicity of STS on A549 cells were performed. Then Different cell lines (16HBE and BEAS-2B) were also used to investigate the effect of STS on RSV replication. The Type IIFNassociated protein (IFN- $\alpha$, IFN- $\beta$ and IP-10) were also detected by ELISA, and IFN-deficient Vero cells were also used to investigate the role of IFN response in STS-modulated RSV replication.

Results

Low concentration of STS potently promoted RSV replication in vitro by increasing virus titers and the expression of RSV N protein, and $25 \mu \mathrm{g} / \mathrm{ml}$ STS reached the maximum effect. While high concentration of STS $(200 \mu \mathrm{g} / \mathrm{ml})$ effectively inhibited virus replication but it may due to the effect of cytotoxicity. STS treatment $(25 \mu \mathrm{g} / \mathrm{ml})$ also showed the same effect in 16HBE and BEAS-2B cells. STS treatment did not impaired Type I interferon (IFN) induction and also promoted RSV replication in IFN-deficient Vero cells.

\section{Conclusion}

STS promoted RSV replication in vitro by IFN-independent mechanism. Our results indicated that STS treatment should be avoided in clinical RSV-related diseases.

\section{Introduction}

Respiratory syncytial virus (RSV) is a leading cause of viral respiratory tract infection in young children and elderly people worldwide, causing more deaths than influenza each year. RSV infects nearly all children during the first 2 years of life[1, 2]. Severe RSV infection in childhood may be associated with recurrent wheezing and asthma[3]. The RSV genome contains 10 genes encoding 11 proteins. Helical nucleocapsids is the template for RSV polymerase transcription and replication, which are formed by viral RNA encapsidated by the nucleocapsid( $\mathrm{N}$ ) protein [4]. The heightened viral load caused by the massive replication of RSV is closely related to the disease severity[5-7]. However, there is no available vaccine nor antiviral treatment against RSV[4,5].Therefore, identification of drug that regulates viral replication may contribute to clinical management of disease. 
Sodium tanshinone IIA sulfonate (STS) is a derivative of tanshinone IIA (Tan IIA), which is a main active lipophilic constitute extracted from the dried roots of traditional Chinese medicine Danshen (Salvia miltiorrhiza Bge)[8]. STS presents a variety of pharmacological activities, such as anti-inflammation, antioxidant, anti-apoptosis and anti-coagulation et al. It has been approved and widely used for treatment of cardiovascular diseases[8-11]. Respiratory viral infections may cause to thrombocytosis and even coagulation dysfunction in children, and the most common virus is RSV[12-14].Moreover, RSV is also considered to be an important cause of lower respiratory tract infection in the elderly and patients with underlying chronic cardiopulmonary diseases[2, 15], and patients with cardiopulmonary disease had higher utilization of healthcare for RSV-related diseases and worse outcomes[2]. Moreover】adults hospitalized due to RSV infection is complicated by cardiovascular events in $14-22 \%$, including acute coronary syndrome, worsening congestive heart failure, and arrhythmias[2].Therefore, STS is also used clinically in adults and children with RSV-related diseases.

In recent years, STS was reported to have the antiviral activity for viruses such as Marek's disease virus (MDV)[16-19], Porcine reproductive and respiratory syndrome virus (PRRSV)[20-22]. However, no studies have focused on the effects of STS on RSV replication so far. Type I interferon (IFN) response is the critical pathway that defense cells against virus infection by inducing the expression of hundreds of IFN-

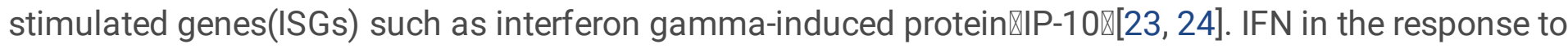
RSV infection is related to viral load『rate of virus clearance and the severity of disease[5-7].

Thus $\varangle$ we aimed in the study to investigate the effect of STS on RSV replication in vitro and the relationship between the IFN response. We first studied the antiviral activity of different concentration of STS by applying it to RSV infected A549 cells. We found that low concentration of STS promoted RSV replication mainly at the late stage of infection. Then we demonstrated the same effect of STS in other cell lines such as $16 \mathrm{HBE}$ and BEAS-2B. Finally, we provided evidence that STS promoted RSV replication in an IFN-independent mechanism.

\section{Materials And Methods}

\section{Virus and cells}

Cell lines of 16HBE (human bronchial epithelial cells), BEAS-2B (human bronchial epithelial transformed cell) and Vero cells (African green monkey kidney cells) were obtained from ATCC. HEp-2 (laryngeal squamous cell carcinoma cells) and A549 (lung adenocarcinoma cells) cells were obtained from Prof.

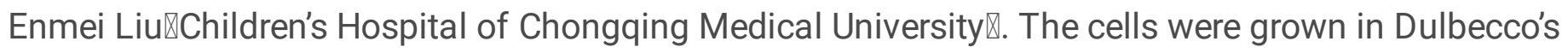
modified Eagle medium (DMEM) supplemented with 10\% fetal bovine serum (FBS) (AusGeneX).

All RSV infections were carried out by RSV A2 strain, which was obtained from Prof. Enmei Liu囚Children's

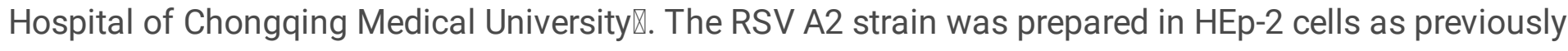
described [7]. Briefly $ه$ HEp-2 cells inoculated with RSV A2 were incubated with DMEM containing $2 \%$ FBS at $37^{\circ} \mathrm{C}(5 \% \mathrm{CO} 2)$ until the cells exhibited $>90 \%$ cytopathic effect (CPE). The cultures were then frozen and thawed, and the cell lysates containing viral particles were collected and centrifuged at $4{ }^{\circ} \mathrm{C} \triangle$ at 12000 
rpm for 10 minutes to remove the cell debris. The viral stocks were titrated by agarose plaque assay, and then stored at $-80^{\circ} \mathrm{C}$ in small aliquots.

\section{STS treatment}

In STS treatment assays, virus at a multiplicity of infection (MOI) of 0.01 was added to $80 \%$ confluent cells and left to adhere at $37^{\circ} \mathrm{C}$ for $2 \mathrm{~h} \otimes$ followed by washing twice with PBS to remove unabsorbed virus. Then the cells were cultured in DMEM supplemented with different concentration of sodium tanshinone IIA sulfonate (STS, MedChem Express, New Jersey, USA) $(12.5 \rrbracket 25 \rrbracket 50 \rrbracket 100$ and $200 \mu \mathrm{g} / \mathrm{ml}$ or only $25 \mu \mathrm{g} / \mathrm{ml}$ ) $[17,19,21]$ and $2 \%$ FBS, cells or supernatants samples were collected at $12 \mathrm{~h}, 24 \mathrm{~h}, 36 \mathrm{~h}, 48 \mathrm{~h}$ or $60 \mathrm{~h}$ post RSV infection. In STS efficiency assay (percent of inhibition or promotion), virus infection was similar, except the cells were covered with the mixture consisted with 1\% agar and 2×DMEM supplemented with $5 \%$ FBS containing different concentration of STS $(0-200 \mu \mathrm{g} / \mathrm{ml})$. STS efficiency was defined as the ratio of plaques formed on treated versus untreated cells[25].

\section{Virus titrations}

Supernatants of RSV infected cells were collected, and tittered by plaque assay on HEp-2 monolayers with neutral red staining. Viral titers were calculated as plaque-forming units (PFU) as previously described[25].

\section{Cell Viability tests}

Cell viability testing was done by using a Cell Counting Kit-8 (CCK8) according to the manufacturer's instructions. Briefly, $1 \times 10^{\wedge} 5$ A549 cells were seeded in 96 -well plates. They were left to adhere overnight and then treated with STS $(0-200 \mu \mathrm{g} / \mathrm{ml})$ for $48 \mathrm{~h}$, then the supernatants were removed and cells were washed with PBS for three times. CCK8 reagent was added to the wells for $1 \mathrm{~h}$ at $37^{\circ} \mathrm{C}$. Then the OD values were measured at $450 \mathrm{~nm}$ with a microplate reader and cell viability was calculated.

\section{Immunofluorescence tests}

Cells were grown in 24-well plates to about $80 \%$ confluence, then infected with RSV and treated with STS as described above. The infected cells were washed three times with PBS and fixed in $4 \%$ formaldehyde for 20 min, followed by 1\% BSA (Solarbio, Beijing, China) with 0.3\% Triton X-100 (Solarbio, Beijing, China) in PBS treatment for $30 \mathrm{~min}$. Cells were then stained with a mouse monoclonal antibody against RSV N (1:200, mouse; Abcam, Cambridge, UK) in $1 \%$ BSA at $37^{\circ} \mathrm{C}$ for $2 \mathrm{~h}$. Cells were washed with PBS for three times, then FITC 488-conjugated goat anti-mouse secondary antibody (1:300; Bioss, China) were incubated at $37^{\circ} \mathrm{C}$ for $1 \mathrm{~h}$. Images were obtained using a Olympus inverted immunofluorescence microscope.

\section{ELISA analysis}


The levels of IFN-a, IFN- $\beta$ and IP-10 in supernatants of infected cells were measured with commercial ELISA kits of IFN- $\alpha$, IFN- $\beta$ and IP-10 (Neobioscience, Wuhan, China) according to the manufacturer's instructions.

\section{Western blots analysis}

Cells in 6-well plates were washed twice with PBS, then protein was extracted using a total protein extraction kit (KeyGEN, Nanjing, China). After protein quantification using a BCA assay reagent (Solarbio, Beijing, China), equal amounts of protein $(60 \mu \mathrm{g})$ were separated on $12 \%$ sodium dodecyl sulfatepolyacrylamide gel electrophoresis (SDS-PAGE) gel and then transferred onto polyvinylidene difluoride (PVDF) membranes (Millipore, Billerica, MA). The membranes were blocked and then incubated with a mouse antibody against RSV N (1:1000, mouse; Abcam, Cambridge, UK) or GAPDH (1:5,000, rabbit; Bioss, China) at $4^{\circ} \mathrm{C}$ overnight. Then, an HRP-conjugated goat anti-mouse secondary antibody (1:5,000; Bioss, China) or a goat anti-rabbit secondary antibody (1:5,000; Bioss, China) were used to detect the presence of the respective protein bands. Signals were quantified using the Quantity One software (Bio-Rad, Hercules, CA) and normalized relative to GAPDH.

\section{Statistical Analysis}

The GraphPad Prism 5.0 software was used for data analysis. All results are expressed as the mean \pm SEM unless otherwise stated. Statistical significance was analyzed by a student's t-test and ANOVA. Differences were considered significant at $\mathrm{P}<0.05$.

\section{Ethics statement}

The study was approved by the Ethics Committees of the China Guizhou Provincial People's Hospital (Approve number 2018058).

\section{Results}

\section{STS affects CPE and virus titer in RSV-infected A549 cells}

In order to investigate the impact of STS on RSV replication and to screen the best concentration of STS, RSV infected A549 cell model was established (MOI=0.01). After adsorption for $2 \mathrm{~h}$, the cells were washed twice with PBS, followed by treatment with different concentration of STS $(12.5 \rrbracket 25 \rrbracket 50 \rrbracket 100$ and $200 \mu \mathrm{g} / \mathrm{ml}$ ) in DMEM with $2 \%$ FBS. Then the cultures were left to grow for $48 \mathrm{~h}$ and obvious CPE can be observed. RSV infection of confluent A549 monolayers produced plaques of about 1.5-2.5 mm in diameter after $48 \mathrm{~h}$ of incubation. STS treatment significantly induced the numbers and size of plaques when the concentration was lower than $100 \mu \mathrm{g} / \mathrm{ml}$, and the $25 \mu \mathrm{g} / \mathrm{ml}$ STS gave a maximum effect. However, both CPE and the numbers and size of plaques were obviously suppressed when STS was at the concentration of $200 \mu \mathrm{g} / \mathrm{ml}$ (Table 1). To further determine the virus titers, the supernatants from 25 and $200 \mu \mathrm{g} / \mathrm{ml}$ of STS-treated cells were tested. The virus recovered from only RSV infected cells titered at $7.7 * 10^{\wedge} 6 \mathrm{PFU} / \mathrm{ml}$. However, the titers reached $3.7 * 10^{\wedge} 8 \mathrm{PFU} / \mathrm{ml}$ when treated with $25 \mu \mathrm{g} / \mathrm{ml} \mathrm{STS}(\mathrm{p} \otimes 0.05 \rrbracket$ 
Figure 1). While treated with $200 \mu \mathrm{g} / \mathrm{ml}$ of STS significantly suppressed the virus yield and titered at only $1.3^{\star} 10^{\wedge} 3 \mathrm{PFU} / \mathrm{ml}(\mathrm{p} \otimes 0.001 \otimes$ Figure 1$)$. The results indicated that the low concentration of STS effectively promoted RSV replication in A549 cells while the high concentration of STS $(200 \mu \mathrm{g} / \mathrm{ml})$ potently suppressed virus replication.

\section{STS affects the expression of RSV N protein in A549 cells}

To investigate the effect of different STS on the expression of RSV N protein, the RSV N protein was detected by Western Blot at 48h post RSV infection. The results demonstrated that the levels of RSV N protein were significantly increased when the concentration of STS was lower than $100 \mu \mathrm{g} / \mathrm{ml}(\mathrm{p} \otimes 0.05-$ 0.001 Figure $2 A)$, and the $25 \mu \mathrm{g} / \mathrm{ml}$ STS gave a maximum effect ( $\mathrm{p} \otimes 0.001 \otimes$ Figure $2 \mathrm{~A})$. However, RSV $\mathrm{N}$ protein was greatly suppressed when STS was at the concentration of $200 \mu \mathrm{g} / \mathrm{ml}(\mathrm{p} \otimes 0.05 \otimes F i g u r e 2 A)$. The immunofluorescence staining further demonstrated that the expression of RSV N protein was significantly increased and the virus particles were released diffusely to form more infected cells when STS was at the concentration of $25 \mu \mathrm{g} / \mathrm{ml}$ compared with RSV control group. While RSV N protein was clearly decreased and only limited infected cells were found when treated with $200 \mu \mathrm{g} / \mathrm{ml}$ STS (Figure 2B). The results indicated that STS affected the express of RSV N protein, which were consistent with the increase of CPE and virus titer. Therefore, the expression of RSV N protein may represent the virus titer.

\section{Cytotoxicity of STS on A549 cells}

We identified that $200 \mu \mathrm{g} / \mathrm{ml}$ STS significantly suppressed RSV replication. To examine whether STS had cytotoxicity effect on A549 cells, different concentration of STS $(12.5 \otimes 25 \otimes 50 \otimes 100$ and $200 \mu \mathrm{g} / \mathrm{ml})$ were added into the culture medium for 48 hours. As revealed in the CCK8 test, cell growth was not affected when the concentration of STS was lower than $50 \mu \mathrm{g} / \mathrm{ml}$. However, high concentration of STS (100 and $200 \mu \mathrm{g} / \mathrm{ml}$ ) treatment significantly showed cytotoxicity on the growth of A549 cells ( $\mathrm{p} \otimes 0.01-0.001$, Figure $3 A$ ) and the effect of $200 \mu \mathrm{g} / \mathrm{ml}$ STS is more obvious ( $\mathrm{p} \otimes 0.001$, Figure $3 \mathrm{~A})$. Moreover, it was observed that $200 \mu \mathrm{g} / \mathrm{ml}$ STS caused an increase in cell size (Figure 3B). Therefore, we supposed that the antiviral effect of high concentration of STS was most probably due to the obvious cytotoxicity. Thus, $25 \mu \mathrm{g} / \mathrm{ml}$ STS was selected for the further study due to no cytotoxicity and had the best effect in promoting RSV replication.

\section{Kinetics of STS-regulated RSV replication in A549 cells}

Then Western Blot and indirect immunofluorescence staining were used to analyze the effect of $25 \mu \mathrm{g} / \mathrm{ml}$ STS on the expression of RSV N protein at 24-48 h post RSV infection. As shown in Western Blot, there was almost no detectable band (N protein) at 24h, and STS didn't significantly increase the expression of RSV N protein at $36 \mathrm{~h}$. However, the expression of RSV N protein was obviously increased at $48 \mathrm{~h}$ post RSV infection ( $p$ \0.001هFigure 4A). Immunofluorescence staining also showed only limited infected cells were found in both groups at 24 and 36h. However, STS significantly increased the expression of RSV N protein and more infected cells and virus particles were found at 48h post RSV infection (Figure 4B). 
Therefore, the promotion effect of STS on RSV replication in A549 cells is mainly at the late stage of infection.

\section{STS promotes RSV replication in different cell lines}

Due to A549 is a tumor-derived airway epithelial cell, we then investigate whether STS also had the same effect in other normal airway-derived cell lines that commonly used in RSV studies, such as 16HBE and BEAS-2B. As the results shown, at $60 \mathrm{~h}$ post RSV infection in both groups, STS treatment significantly induced more obvious CPE both in 16HBE (Figure 4A) and BEAS-2B cells (Figure 4D). Western blot demonstrated increased expression of RSV N protein in both16HBE ( $p$ \0.001, Figure 4B) and BEAS-2B cells ( $p \otimes 0.05$, Figure $4 E$ ). Immunofluorescence staining also showed the consistent results and more infected cells both in 16HBE (Figure 4C) and BEAS-2B cells (Figure 4F). Thus, the effect of promotion RSV replication by STS in vitro was independent of epithelial cell types.

\section{The effect of promotion RSV replication of STS is IFN-independent}

Innate antiviral responses characterized by the induction of IFN- $\alpha$, IFN- $\beta$ is the critical first line of defense against virus infection[23, 24]. We asked whether the promotion of RSV replication by STS is due to the suppression of IFN signaling. To answer this question, $25 \mu \mathrm{g} / \mathrm{ml}$ STS treated supernatants of $12-48 \mathrm{~h}$ post RSV infection were collected, and IFN- $a$ IFN $-\beta$ and IP-10 were examined by ELISA. Results showed that

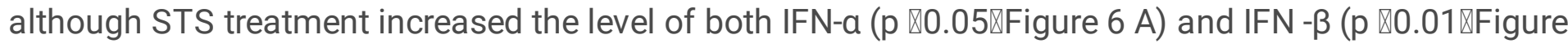
$6 \mathrm{~B}$ ) in supernatants at $48 \mathrm{~h}$ post RSV infection, which were opposite to our hypothesis, though IP-10, the critical ISG induced by IFN, was reduced due to STS treatment ( $p \otimes 0.05-0.01 \otimes$ Figure $6 \mathrm{C}$ ), suggested that STS treatment did not inhibit the induction of IFN. We further infected Vero cells that are naturally lacking type I-IFN genes[26]. Results showed at $60 \mathrm{~h}$ post RSV infection, STS treatment also significantly induced more obvious CPE in Vero cells (Figure 6D), Western blot demonstrated increased expression of RSV N protein ( $\mathrm{p} \otimes 0.01$, Figure $6 \mathrm{E}$ ) and immunofluorescence staining showed the consistent results and more infected cells (Figure 6F). The above results clearly demonstrated that the promotion effect of STS on $\mathrm{RSV}$ replication is not due to impaired IFN response.

\section{Discussion}

In this current study, we confirmed that STS affected RSV replication in vitro. Low concentration of STS potently promoted RSV replication in A549 cells mainly at the late stage of infection, while high concentration of STS effectively inhibited virus replication. However, high concentration of STS was detrimental to cell growth, while low concentration of STS had no cytotoxicity. Low concentration of STS showed the same effect in other cell lines such as 16HBE囚BEAS-2B and even the IFN-deficient Vero cells. We demonstrated that STS promoted RSV replication in vitro by IFN-independent mechanism.

STS is one of the derivatives of tanshinone IIA (Tan IIA), which is a main lipophilic component of traditional Chinese medicine Danshen. Due to the multiple activities, there are several available drugs which contain STS or were developed from Danshen, including Tanshinone IIA Sulfonate injections [8]. 
These drugs have been widely used in China to treat various diseases, particularly cardiovascular disease and cerebral vascular diseases with few side effects [8]. STS is also used clinically in adults and children with RSV-related diseases, such as those with cardiovascular underlying diseases or complications in adults [2,15], and those with thrombocytosis or coagulation dysfunction in children[12-14].

Many compounds present in Danshen have been showed to have potent antiviral activity against Enterovirus 71 infection[27]هHuman Immunodeficiency Virus[28]هHepatitis B virus[29], Human papilloma virus[30]. Sun $\mathrm{N}$ et al. reported that STS had the antiviral activity effect against MDV both in vivo and in vitro[16-19]. They found that STS at 31.25-250 $\mathrm{gg} / \mathrm{ml}$ could effectively inhibit the MDV replication in chicken embryo fibroblasts cells in a dose-dependent manner, mainly by inhibition the expression of several virus genes and proteins. Meanwhile, the same researchers also demonstrated the anti-PRRSV effect of STS by using Marc- 145 cells and found $62.5 \mu \mathrm{g} / \mathrm{ml}$ STS showed the antiviral effect, and the potential mechanism may due to the anti-apoptosis and anti-autophagy[20-22].

In this study, by using RSV infected A549 cell model, we identified the effect of STS on RSV replication. But STS showed completely opposite effects on RSV replication between high and low concentrations. When treated with high concentration $\nabla 200 \mu \mathrm{g} / \mathrm{m}$ |ख of STS, RSV infected A549 cells showed reduced CPE, decreased virus titers, decreased expression of $\mathrm{N}$ protein and limited infected cells, suggested that high concentration $\varangle 200 \mu \mathrm{g} / \mathrm{ml}$ \of RSV effectively inhibited RSV replication in A549 cells (Table1®Figures 1 and 2). When treated with low concentration $\nabla \mathbf{0} 100 \mu \mathrm{g} / \mathrm{ml}$ \of STS, especially with $25 \mu \mathrm{g} / \mathrm{ml}, \mathrm{RSV}$ infected A549 cells showed more obvious CPE, increased virus titers, increased expression of $\mathrm{N}$ protein and diffused release of virus particles and more infected cells (Table1هFigs 1 and 2), suggested that low concentration

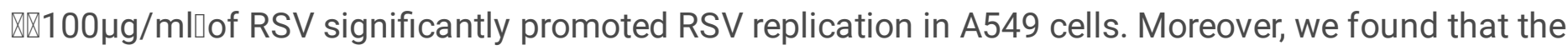
expression of $\mathrm{N}$ protein was consistent with the CPE and virus titers, suggested that $\mathrm{N}$ protein may represent the viral replication, which was consistent with others results[31]. We demonstrated that high concentration of STS $\otimes 100-200 \mu \mathrm{g} / \mathrm{ml}$ | showed cytotoxicity to cell growth, which may be the reason for the antiviral effect of $200 \mu \mathrm{g} / \mathrm{ml} \mathrm{STS}$. However, though $100 \mu \mathrm{g} / \mathrm{ml}$ STS also showed certain cytotoxicity to cell growth, increased viral replication was still observed. So, we concluded that STS promoted RSV replication in general. Our results were different with that of Sun $N$ et al. [16-22], implying that the effect of STS may differ amongst viruses, which need to be further studied.

We demonstrated that low concentration especially $25 \mu \mathrm{g} / \mathrm{ml}$ of STS had no cytotoxicity and had the best effect in promoting RSV replication. Then $25 \mu \mathrm{g} / \mathrm{ml}$ of STS was selected for further studies. Kinetics of RSV replication study showed the difference of viral replication was only observed in 48h post RSV infection, suggested STS promoted RSV replication possibly in the late stage of RSV infection.

Cell lines may alter some of the structural patterns of the yield virus, which may in turn affect virus infectivity[32-34]. Some receptors associated with viral infection may differ between tumor cells and welldifferentiated ciliated epithelial cells[35]. Due to A549 is a tumor-derived airway epithelial cell, other normal airway-derived cell lines were used to further clarify the effect of STS on promotion RSV 
replication. By using 16HBE and BEAS-2B cells, we demonstrated that the promotion effect of STS on RSV replication is independent of cell lines.

Antiviral response characterized by the induction of IFN- $a$, IFN- $\beta$ and ISGs such as IP-10 are critical in inhibition viral replication [23, 24], and are known in related to viral load and disease severity in RSV infection[5-7]. However, we found that STS treatment oppositely increased the induction of both IFN-a, IFN- $\beta$ at 48 hours in response to RSV. However, IP-10, which directly acts as an antiviral ISG was not increased, suggested STS did not impaired IFN induction in response to RSV. STS treated IFN-deficient Vero cells also showed more obvious CPE, increased expression of RSV N protein, further suggested that the promotion effect of STS on RSV replication was IFN-independent.

\section{Conclusions}

This study is the first report to demonstrate that low concentration of STS promoted RSV replication, which was cell lines-independent and IFN-independent. Treatment with STS in RSV infection substantially promoted RSV replication. Our results suggested that STS should be avoided in clinical RSV-related diseases.

\section{Abbreviations}

RSV: Respiratory syncytial virus; STS: Sodium tanshinone IIA sulfonate;

IFN: Interferon; MDV: Marek's disease virus; PRRSV: Porcine reproductive and respiratory syndrome virus; ISGs: IFN-stimulated genes;IP-10:Interferon gamma-induced protein;16HBE: Human bronchial epithelial cells; BEAS-2B:Human bronchial epithelial transformed cell;HEp-2: laryngeal squamous cell carcinoma cells;A549: Lung adenocarcinoma cells; DMEM: Dulbecco's modified Eagle medium; FBS: Fetal bovine serum; MOIヌMultiplicity of infection囚CPE: Cytopathic effect; PFU: Plaque-forming units; CCK8: Cell Counting Kit-8

\section{Declarations}

\section{Acknowledgments}

We thank all the staff of the Central Laboratory for their support and helps in this study.

\section{Authors' contributions}

$Z Y, X J, Y L, Y L, L S$ and $L W$ performed experiments and analyses. FY,LF,EL

and $\mathrm{YC}$ conceived the study, designed and analysed experiments. $\mathrm{ZY}$ and $\mathrm{XJ}$ wrote the manuscript. All authors have read and approved the final manuscript.

\section{Funding}


This work was supported by the National Natural Science Foundation of China [81860003 and 81960001], Scientific and technological research project of traditional Chinese medicine and ethnic medicine of Guizhou Provincial Administration of traditional Chinese Medicine区QZYY-2018-010区, Science and Technology Fund project of Guizhou Health and Family Planning Commission (gzwjw2018-1-048), Fund of the Science and Technology Department of Guizhou Province ([2018]2785) and Cultivation fund of National Natural Science Foundation of China (Talents of Qiankehe Platform [2018]5764-02).

\section{Availability of data and materials}

Not applicable.

\section{Ethics approval and consent to participate}

Not applicable.

\section{Consent for publication}

Not applicable.

\section{Competing interests}

The authors declare that they have no competing interests.

\section{Author details}

${ }^{1}$ Department of Pediatrics, Guizhou Provincial People's Hospital, Guiyang 550002, China

2 Department of Central Laboratory, Guizhou Provincial People's Hospital, Guizhou University, Guiyang 550002 , China

${ }^{3}$ NHC Key Laboratory of Pulmonary Immunological Diseases (Guizhou Provincial People's Hospital), Guiyang 550002, China

${ }^{4}$ Department of Ophthalmology, Guizhou Provincial People's Hospital, Guiyang 550002, China

${ }^{5}$ Clinical Laboratory, Guizhou Provincial People's Hospital, Guiyang 550002, China

${ }^{6}$ Department of Respiratory Medicine, Children's Hospital of Chongqing Medical University, Chongqing 400014, China

\section{References}

1. Shi T, McAllister DA, O'Brien KL, Simoes EAF, Madhi SA, Gessner BD, Polack FP, Balsells E, Acacio S, Aguayo C, et al: Global, regional, and national disease burden estimates of acute lower respiratory 
infections due to respiratory syncytial virus in young children in 2015: a systematic review and modelling study.Lancet 2017, 390:946-958.

2. Ivey KS, Edwards KM, Talbot HK: Respiratory Syncytial Virus and Associations With Cardiovascular Disease in Adults.J Am Coll Cardiol 2018, 71:1574-1583.

3. Karron RA, Zar HJ: Determining the outcomes of interventions to prevent respiratory syncytial virus disease in children: what to measure? Lancet Respir Med 2018, 6:65-74.

4. Battles MB, McLellan JS: Respiratory syncytial virus entry and how to block it.Nat Rev Microbiol 2019, 17:233-245.

5. Hijano DR, Vu LD, Kauvar LM, Tripp RA, Polack FP, Cormier SA: Role of Type I Interferon (IFN) in the Respiratory Syncytial Virus (RSV) Immune Response and Disease Severity.Front Immunol 2019, 10:566.

6. Antunes KH, Fachi JL, de Paula R, da Silva EF, Pral LP, Dos Santos AA, Dias GBM, Vargas JE, Puga R, Mayer FQ, et al: Microbiota-derived acetate protects against respiratory syncytial virus infection through a GPR43-type 1 interferon response.Nat Commun 2019, 10:3273.

7. Ye Z, Ren L, Tang Z, Deng Y, Xie X, Fu Z, Luo Z, Xu F, Zang N, Liu E: Pulmonary C-fiber degeneration downregulates IFN-gamma receptor 1 via IFN-alpha induction to attenuate RSV-induced airway hyperresponsiveness. Virology 2017, 510:262-272.

8. Zhou ZY, Zhao WR, Zhang J, Chen XL, Tang JY: Sodium tanshinone IIA sulfonate: A review of pharmacological activity and pharmacokinetics.Biomed Pharmacother 2019, 118:109362.

9. Zhang DP, Lu XY, He SC, Li WY, Ao R, Leung FC, Zhang ZM, Chen QB, Zhang SJ: Sodium tanshinone IIA sulfonate protects against Abeta-induced cell toxicity through regulating Abeta process.J Cell $\mathrm{Mol}$ Med 2020, 24:3328-3335.

10. Wu LC, Lin X, Sun H: Tanshinone IIA protects rabbits against LPS-induced disseminated intravascular coagulation (DIC).Acta Pharmacol Sin 2012, 33:1254-1259.

11. Liu XQ, Deng YX, Dai Z, Hu T, Cai WW, Liu HF, Li H, Zhu WL, Li BY, Wang Q, Zhang SJ: Sodium tanshinone IIA sulfonate protects against Abeta1-42-induced cellular toxicity by modulating Abetadegrading enzymes in HT22 cells.Int J Biol Macromol 2020, 151:47-55.

12. Zheng SY, Xiao QY, Xie XH, Deng Y, Ren L, Tian DY, Luo ZX, Luo J, Fu Z, Huang AL, Liu EM: Association between secondary thrombocytosis and viral respiratory tract infections in children.Sci Rep 2016, 6:22964.

13. Mammas I, Koutsaftiki C, Tapaki-Papadopoulou G, Myriokefalitakis N: Respiratory syncytial virus (RSV) bronchiolitis and excessive thrombocytosis.Acta Paediatr 2010, 99:489-490.

14. Visseren FL, Bouwman JJ, Bouter KP, Diepersloot RJ, de Groot PH, Erkelens DW: Procoagulant activity of endothelial cells after infection with respiratory viruses. Thromb Haemost 2000, 84:319324.

15. Zhang Y, Wang Y, Zhao J, Xiong Z, Fan Y, Zhang W, Zou X, Wang C, Han J, Li B, et al: Severity and mortality of respiratory syncytial virus vs influenza $A$ infection in hospitalized adults in China.Influenza Other Respir Viruses 2020. 
16. Zhang JQ, Gu YL, Wu CH, Ma HL, He JP, Bai YS, Li HQ: Effects of sodium tanshinone IIA sulfonate against Marek's disease virus in experimentally infected chickens.Int J Biol Macromol 2013, 58:258262.

17. Wang J, Sun P, Feng Y, Guo J, Sun Y, Lei H, Xu J, Li H: Sodium tanshinone IIA sulfonate affects Marek's disease virus replication by inhibiting gB expression.Pharm Biol 2016, 54:701-704.

18. Sun Y, Niu L, Song M, Zhao X, Sun N, He J, Wu C, Jiang J, Bai Y, Guo J, Li H: Screening compounds of Chinese medicinal herbs anti-Marek's disease virus.Pharm Biol 2014, 52:841-847.

19. Sun N, Cong XM, Jiang JB, Zhao JX, Wang WK, Duan ZB, Hu YL, Lei HM, Li HQ: Sodium tanshinone IIA sulfonate inhibits the meq, ul49 and VP22 expression of Marek's disease virus.Antivir Ther 2014, 19:793-798.

20. Sun N, Sun P, Yao M, Khan A, Sun Y, Fan K, Yin W, Li H: Autophagy involved in antiviral activity of sodium tanshinone IIA sulfonate against porcine reproductive and respiratory syndrome virus infection in vitro.Antivir Ther 2019, 24:27-33.

21. Sun N, Li E, Wang Z, Zhao J, Wang S, He J, Bai Y, Li H: Sodium tanshinone IIA sulfonate inhibits porcine reproductive and respiratory syndrome virus via suppressing $\mathbf{N}$ gene expression and blocking virus-induced apoptosis.Antivir Ther 2014, 19:89-95.

22. Sun N, Zhao X, Bai XY, Niu L, Song MQ, Sun YG, Jiang JB, Li HQ: Anti-PRRSV effect and mechanism of sodium tanshinone IIA sulfonate in vitro.J Asian Nat Prod Res 2012, 14:721-728.

23. Hadjadj J, Yatim N, Barnabei L, Corneau A, Boussier J, Smith N, Pere H, Charbit B, Bondet V, Chenevier-Gobeaux $C$, et al: Impaired type I interferon activity and inflammatory responses in severe COVID-19 patients.Science 2020.

24. Kerr CH, Skinnider MA, Andrews DDT, Madero AM, Chan QWT, Stacey RG, Stoynov N, Jan E, Foster LJ: Dynamic rewiring of the human interactome by interferon signaling.Genome Biol 2020, 21:140.

25. Fata-Hartley CL, Palmenberg AC: Dipyridamole reversibly inhibits mengovirus RNA replication.J Virol 2005, 79:11062-11070.

26. Mosca JD, Pitha PM: Transcriptional and posttranscriptional regulation of exogenous human beta interferon gene in simian cells defective in interferon synthesis.Mol Cell Biol 1986, 6:2279-2283.

27. Chung YC, Hsieh FC, Lin YJ, Wu TY, Lin CW, Lin CT, Tang NY, Jinn TR: Magnesium lithospermate B and rosmarinic acid, two compounds present in Salvia miltiorrhiza, have potent antiviral activity against enterovirus 71 infections. Eur J Pharmacol 2015, 755:127-133.

28. Zhang HS, Chen XY, Wu TC, Zhang FJ: Tanshinone II A inhibits tat-induced HIV-1 transactivation through redox-regulated AMPK/Nampt pathway.J Cell Physio/ 2014, 229:1193-1201.

29. Qi FH, Wang ZX, Cai PP, Zhao L, Gao JJ, Kokudo N, Li AY, Han JQ, Tang W: Traditional Chinese medicine and related active compounds: a review of their role on hepatitis B virus infection.Drug Discov Ther 2013, 7:212-224.

30. Munagala R, Aqil F, Jeyabalan J, Gupta RC: Tanshinone IIA inhibits viral oncogene expression leading to apoptosis and inhibition of cervical cancer.Cancer Lett 2015, 356:536-546. 
31. Yamamoto K, Ogasawara N, Yamamoto S, Takano K, Shiraishi T, Sato T, Tsutsumi H, Himi T, Yokota SI: Evaluation of consistency in quantification of gene copy number by real-time reverse transcription quantitative polymerase chain reaction and virus titer by plaque-forming assay for human respiratory syncytial virus.Microbiol Immunol 2018, 62:90-98.

32. Kwilas S, Liesman RM, Zhang L, Walsh E, Pickles RJ, Peeples ME: Respiratory syncytial virus grown in Vero cells contains a truncated attachment protein that alters its infectivity and dependence on glycosaminoglycans.J Virol 2009, 83:10710-10718.

33. Derscheid RJ, van Geelen A, McGill JL, Gallup JM, Cihlar T, Sacco RE, Ackermann MR: Human respiratory syncytial virus Memphis 37 grown in HEp-2 cells causes more severe disease in lambs than virus grown in Vero cells. Viruses 2013, 5:2881-2897.

34. Rixon HWM, Brown C, Brown G, Sugrue RJ: Multiple glycosylated forms of the respiratory syncytial virus fusion protein are expressed in virus-infected cells.J Gen Viro/ 2002, 83:61-66.

35. Zhang L, Bukreyev A, Thompson Cl, Watson B, Peeples ME, Collins PL, Pickles RJ: Infection of ciliated cells by human parainfluenza virus type 3 in an in vitro model of human airway epithelium. $J$ Virol 2005, 79:1113-1124.

\section{Tables}

Table 1. STS affects RSV induced CPE in A549 cells

\begin{tabular}{|lll|}
\hline STS $(\mu \mathrm{g} / \mathrm{ml})$ & Plaque increment or reduction (\%) a & Relative plaque size b \\
\hline 200 & -78.57 & \pm \\
100 & 33.03 & ++ \\
\hline 50 & 81.25 & +++ \\
25 & 103.57 & ++++ \\
12.5 & 83.93 & +++ \\
\hline 0 & 0 & + \\
\hline
\end{tabular}

STS efficiency was defined as the ratio of plaques formed on treated versus untreated cells.

STS: sodium tanshinone IIA sulfonate

a Values represent the average of two experiments, each done with $n=4$.

b Plaques in the present of STS averaged about $2 \mathrm{~mm}$ in diameter. $\quad \pm,++++,+++,++++$ ( describe what each stands for .)

Figures 


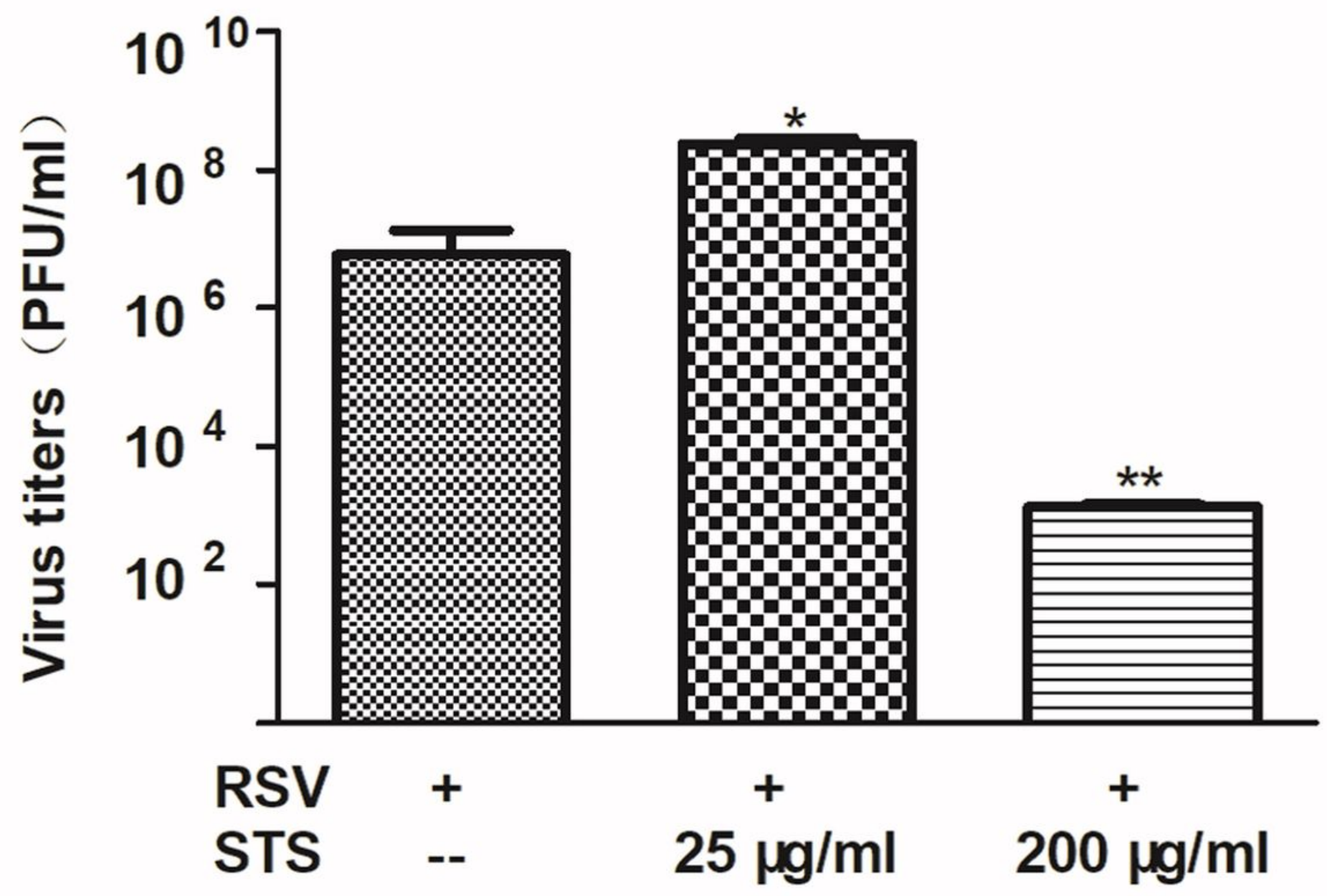

Figure 1

STS treatment affects viral titers post RSV infection in A549 cells. Supernatants from 25 and $200 \mu \mathrm{g} / \mathrm{ml}$ of STS-treated cells were titered by plaque assay. high concentration $\nabla 200 \mu \mathrm{g} / \mathrm{ml}$ \of STS significantly decreased virus titers ( $p \otimes 0.01$ ), while low concentration $\varangle 25 \mu \mathrm{g} / \mathrm{ml} \otimes$ of STS effectively increased virus titers ( $p \otimes 0.05$ ). STS: sodium tanshinone IIA sulfonate. The results represent twice independent experiments $(n=4)$, and all data are presented as the mean \pm SEM. $\left(^{*}\right) p<0.05,\left({ }^{\star *}\right) p<0.01$. 


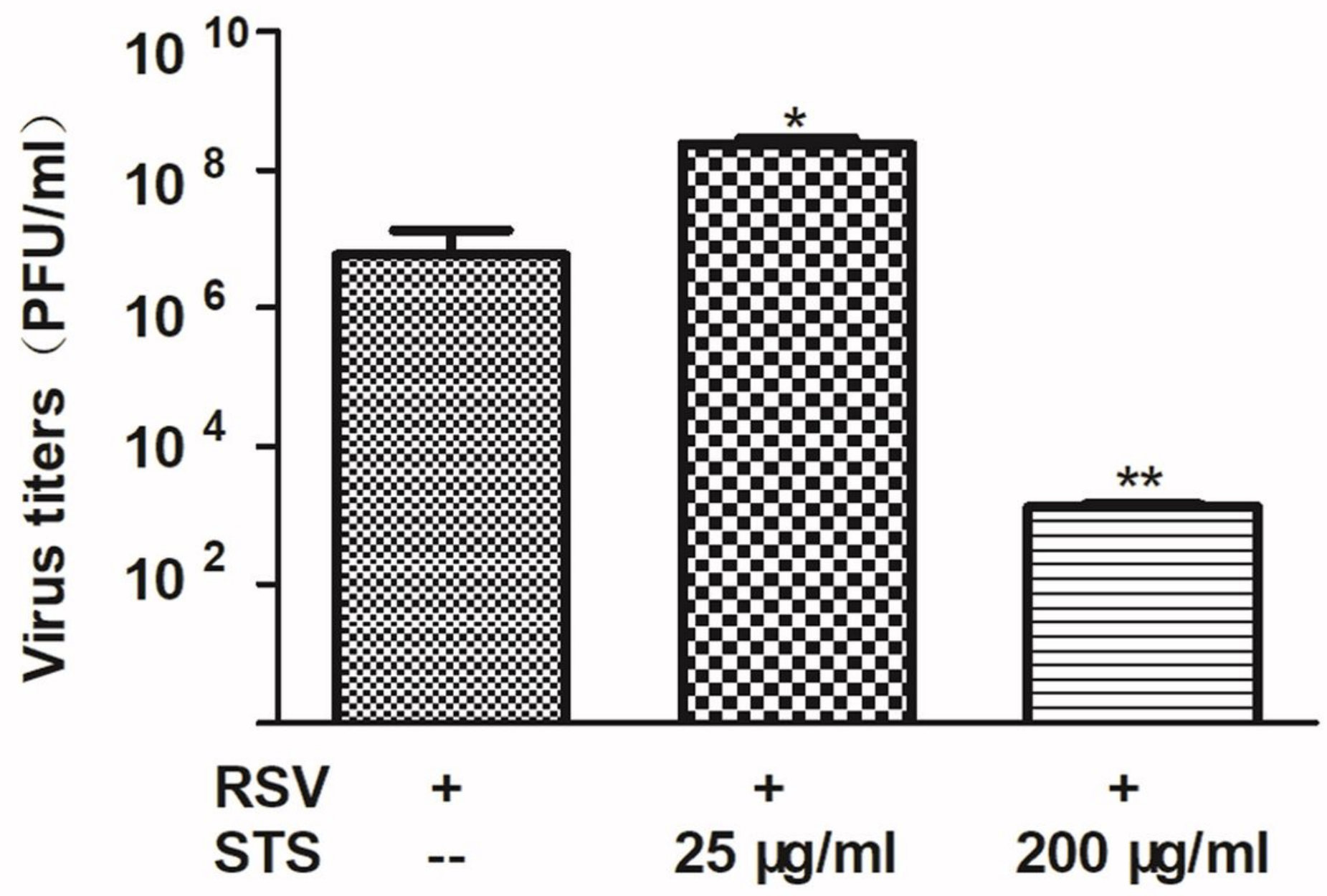

Figure 1

STS treatment affects viral titers post RSV infection in A549 cells. Supernatants from 25 and $200 \mu \mathrm{g} / \mathrm{ml}$ of STS-treated cells were titered by plaque assay. high concentration $\nabla 200 \mu \mathrm{g} / \mathrm{ml}$ \of STS significantly decreased virus titers ( $p \otimes 0.01$ ), while low concentration $\varangle 25 \mu \mathrm{g} / \mathrm{ml} \otimes$ of STS effectively increased virus titers ( $p \otimes 0.05$ ). STS: sodium tanshinone IIA sulfonate. The results represent twice independent experiments $(n=4)$, and all data are presented as the mean \pm SEM. $\left(^{*}\right) p<0.05,\left({ }^{\star *}\right) p<0.01$. 
A
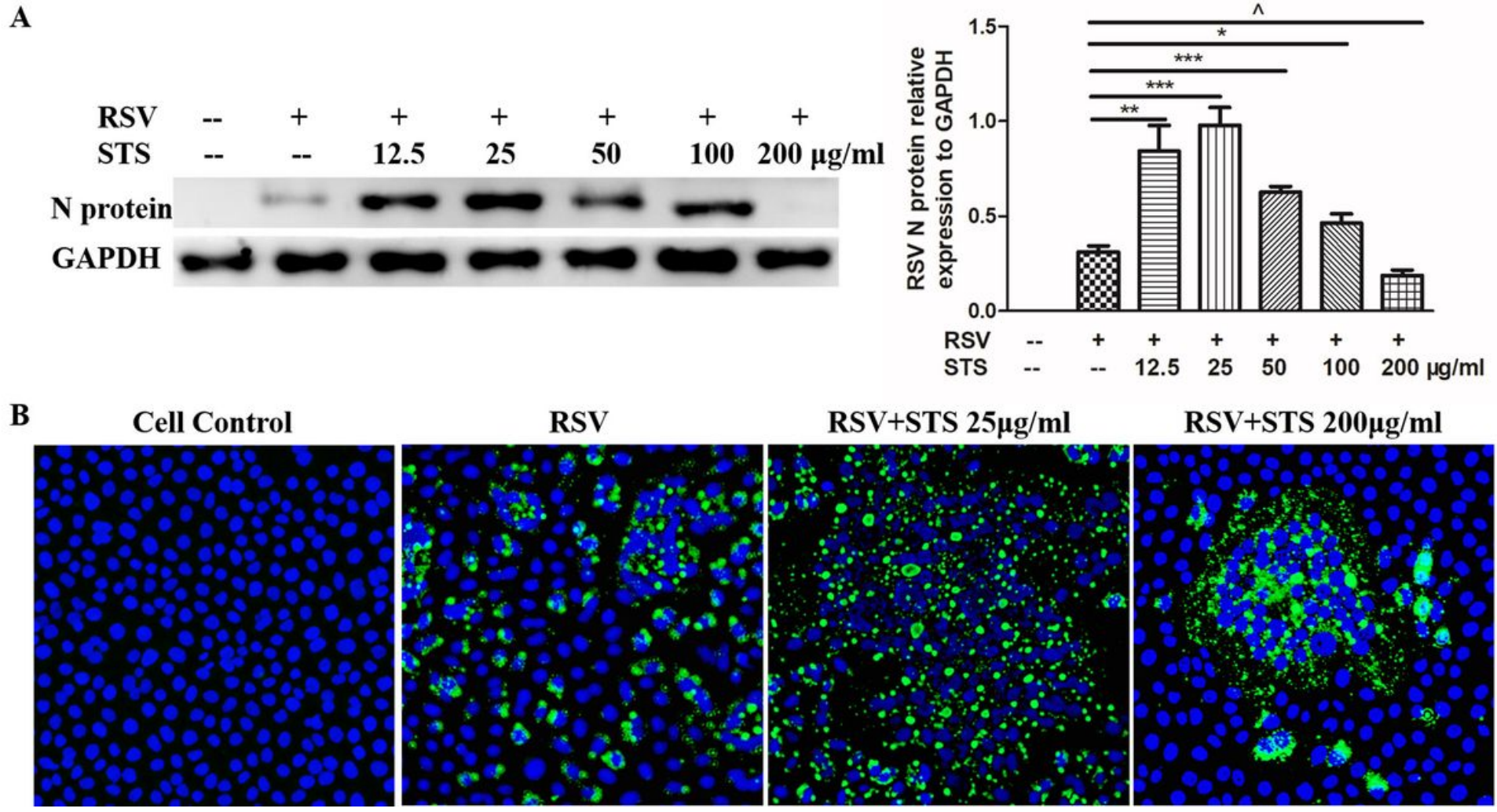

RSV+STS 200 $\mu \mathrm{g} / \mathrm{ml}$

\section{Figure 2}

STS affects the expression of RSV N protein in A549 cells. RSV N protein was detected by Western Blot and immunofluorescence staining at 48h post RSV infection. (A) RSV N protein examined by Western Blot. $\triangle B \otimes R S V N$ protein examined by Immunofluorescence staining. bar=75 $\mu \mathrm{m}$. The results represent three independent experiments $(n=4)$, and all data are presented as the mean \pm SEM. $\left(^{\star}\right) p<0.05,\left({ }^{\wedge}\right) p<$ 0.05 , (**) $p<0.01$, and (***) $p<0.001$. 
A
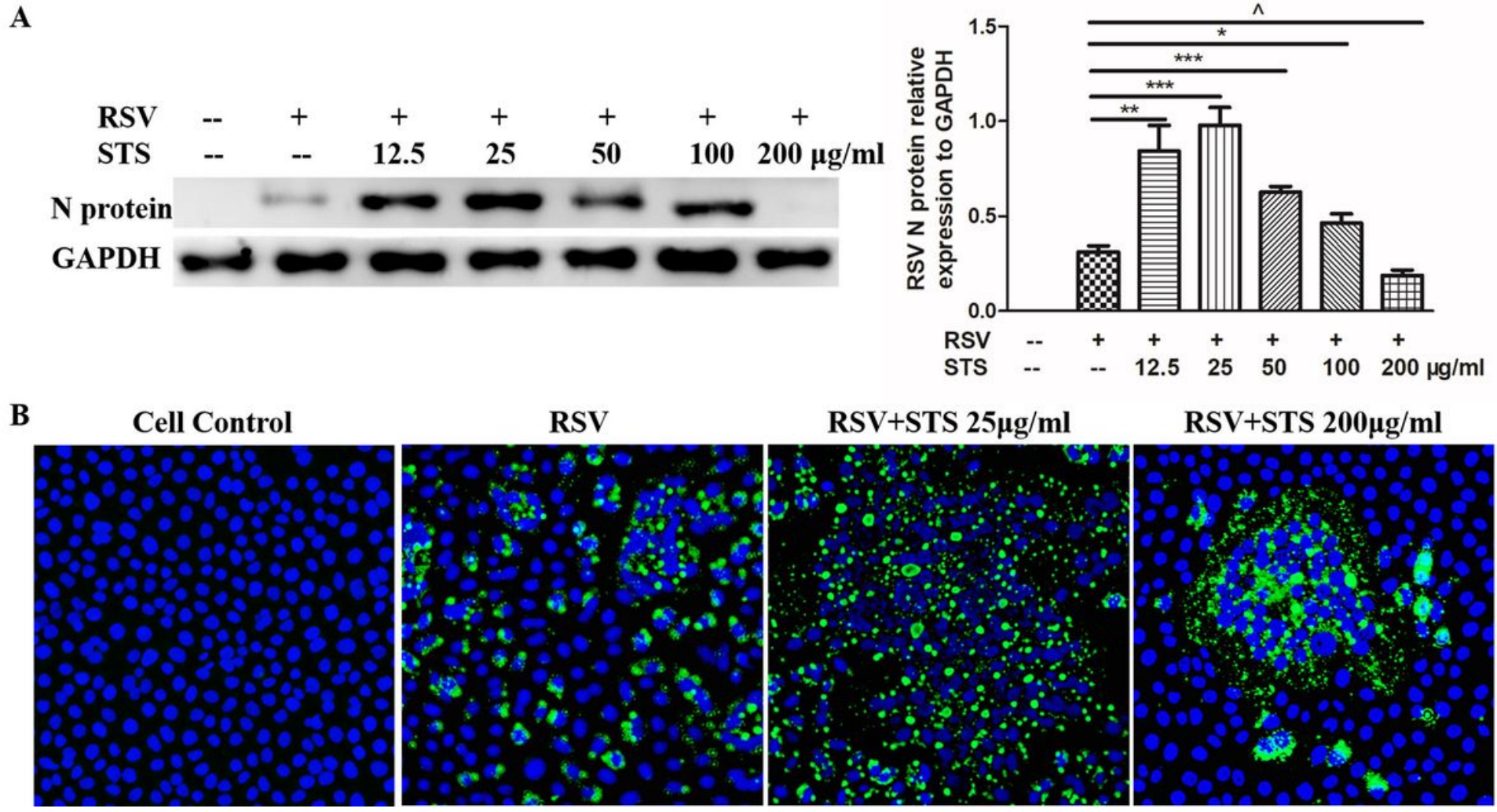

RSV+STS 200 $\mu \mathrm{g} / \mathrm{ml}$

\section{Figure 2}

STS affects the expression of RSV N protein in A549 cells. RSV N protein was detected by Western Blot and immunofluorescence staining at 48h post RSV infection. (A) RSV N protein examined by Western Blot. $\triangle B \otimes R S V N$ protein examined by Immunofluorescence staining. bar=75 $\mu \mathrm{m}$. The results represent three independent experiments $(n=4)$, and all data are presented as the mean \pm SEM. $\left(^{\star}\right) p<0.05,\left({ }^{\wedge}\right) p<$ 0.05 , (**) $p<0.01$, and (***) $p<0.001$. 


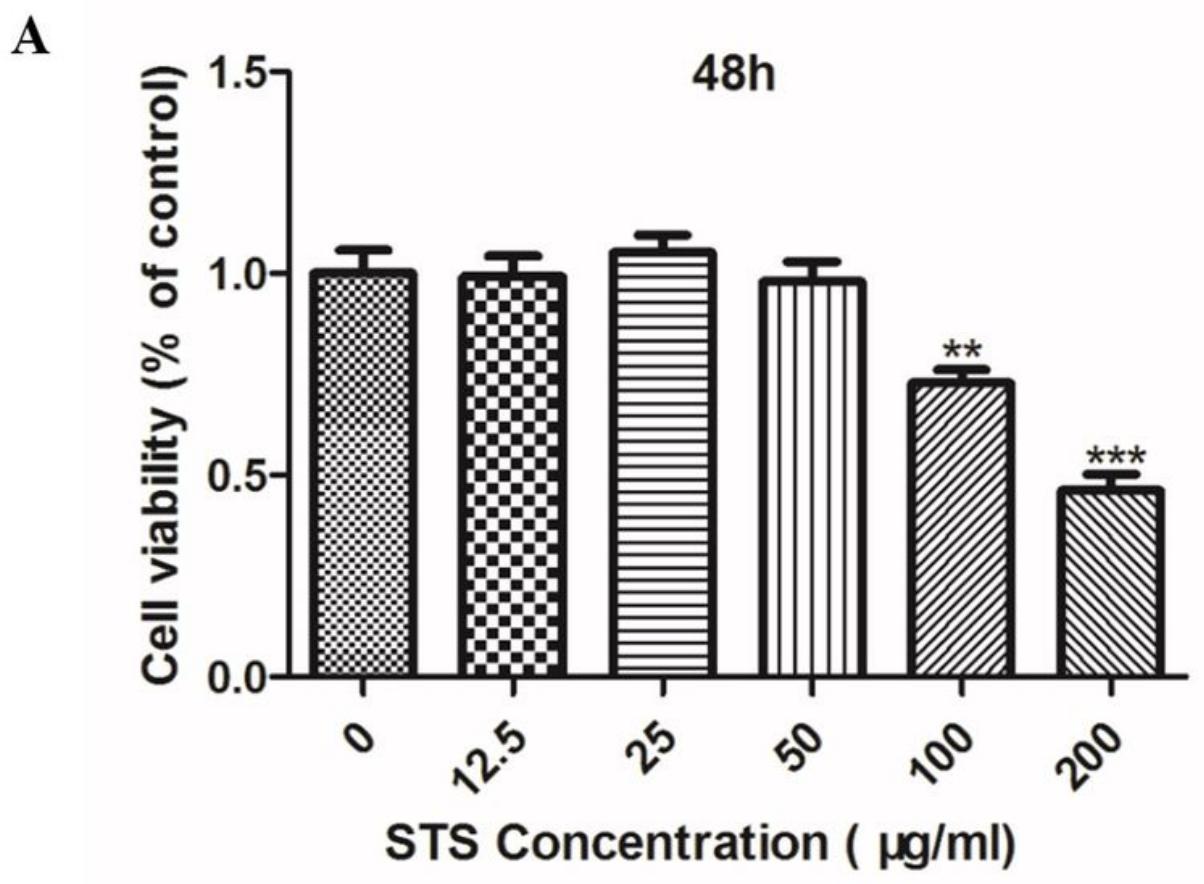

B Cell Control

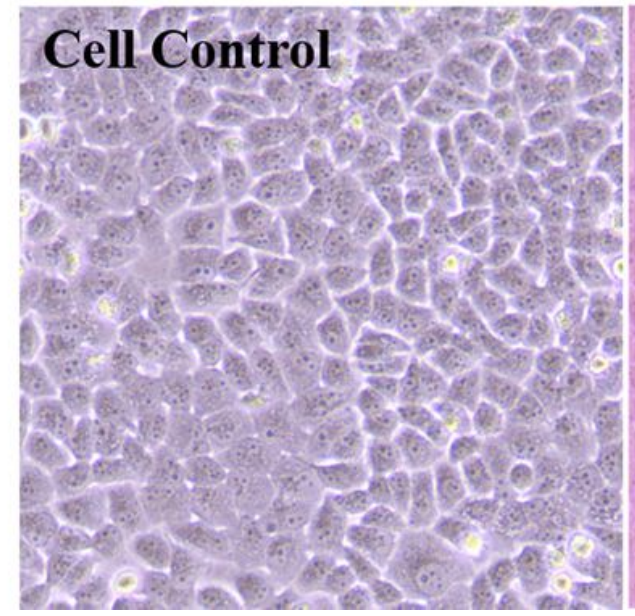

STS $25 \mu \mathrm{g} / \mathrm{ml}$
STS $200 \mu \mathrm{g} / \mathrm{ml}$

\section{Figure 3}

Cytotoxicity of STS on A549 cells. Different concentration of STS $(0-200 \mu \mathrm{g} / \mathrm{ml})$ were added into the medium of A549 cells for 48 hours. CCK8 test was performed to investigate the cytotoxicity and morphology of the cells was observed by microscope. (A) CCK8 test showed high concentration of STS $(100$ and $200 \mu \mathrm{g} / \mathrm{ml})$ treatment significantly showed cytotoxicity and the effect of $200 \mu \mathrm{g} / \mathrm{ml}$ STS is more obvious. (B) $200 \mu \mathrm{g} / \mathrm{ml}$ STS treatment caused an increase in cell size. bar $=150 \mu \mathrm{m}$. The results represent three independent experiments $(n=6)$, and all data are presented as the mean \pm SEM. $\left.{ }^{(* *}\right) p<0.01$, and $(\star \star \star) ~ p<0.001$. 


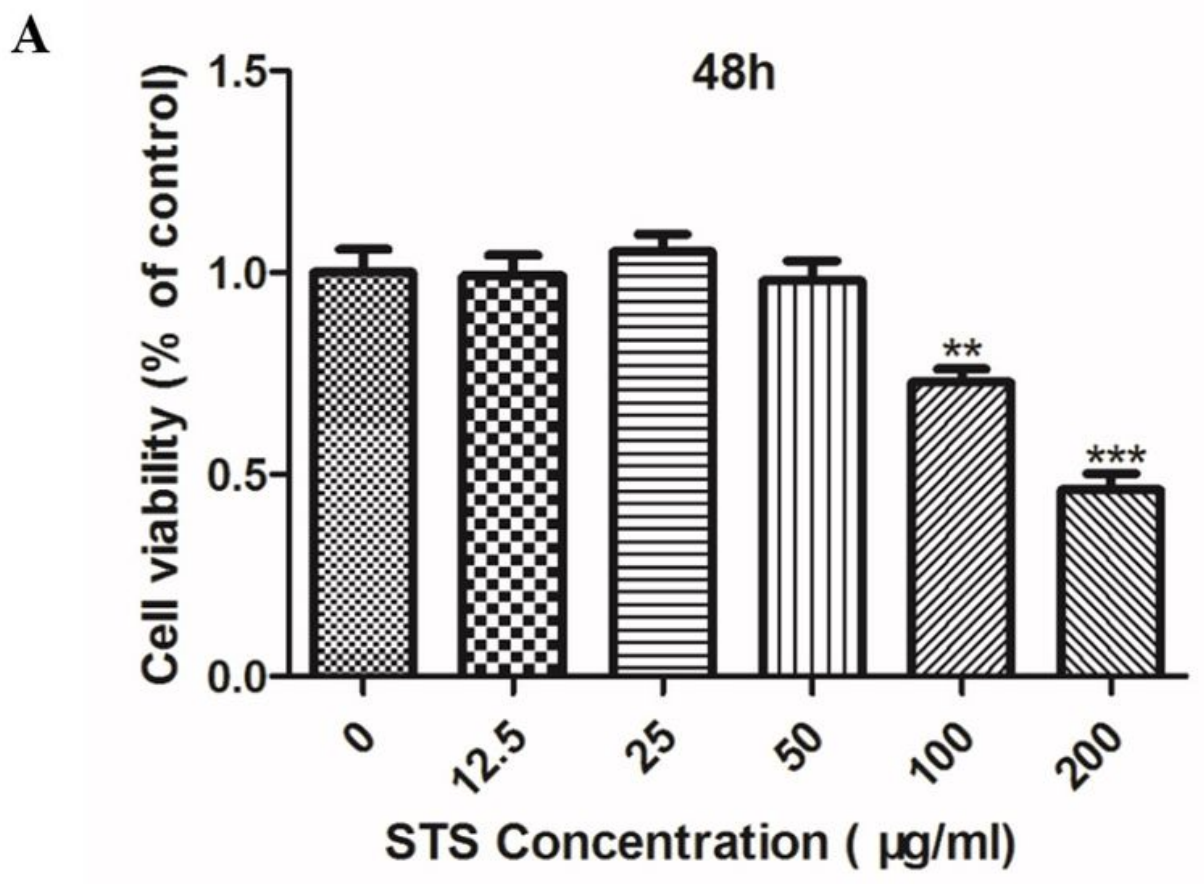

B Cell Control

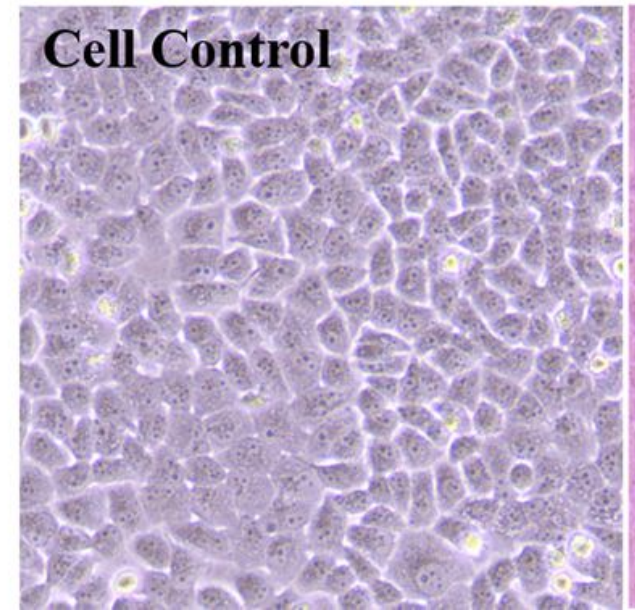

STS $25 \mu \mathrm{g} / \mathrm{ml}$
STS $200 \mu \mathrm{g} / \mathrm{ml}$

Figure 3

Cytotoxicity of STS on A549 cells. Different concentration of STS $(0-200 \mu \mathrm{g} / \mathrm{ml})$ were added into the medium of A549 cells for 48 hours. CCK8 test was performed to investigate the cytotoxicity and morphology of the cells was observed by microscope. (A) CCK8 test showed high concentration of STS $(100$ and $200 \mu \mathrm{g} / \mathrm{ml})$ treatment significantly showed cytotoxicity and the effect of $200 \mu \mathrm{g} / \mathrm{ml}$ STS is more obvious. (B) $200 \mu \mathrm{g} / \mathrm{ml}$ STS treatment caused an increase in cell size. bar $=150 \mu \mathrm{m}$. The results represent three independent experiments $(n=6)$, and all data are presented as the mean \pm SEM. $\left.{ }^{* \star}\right) p<0.01$, and $(\star \star \star) ~ p<0.001$. 


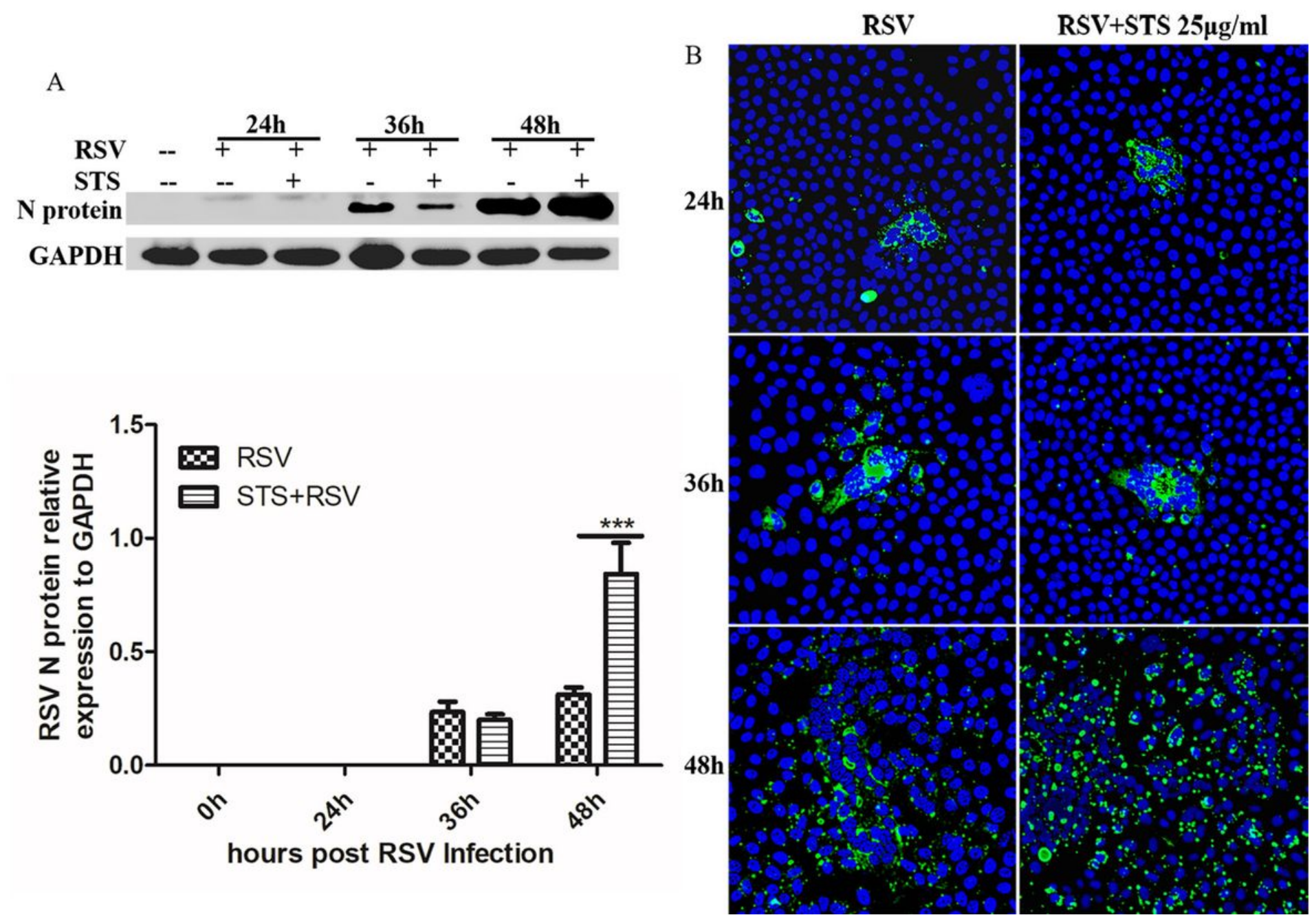

Figure 4

Kinetics of STS-regulated RSV replication in A549 cells. Western Blot and immunofluorescence staining were used to analyze the effect of $25 \mu \mathrm{g} / \mathrm{ml}$ STS on the expression of RSV N protein at 24-48 h post RSV infection. (A) RSV N protein examined by Western Blot.囚B囚RSV N protein examined by Immunofluorescence staining. bar $=75 \mu \mathrm{m}$. The results are representative of three independent experiments $(n=4)$, and all data are presented as the mean \pm SEM. $(* \star *) p<0.001$. 


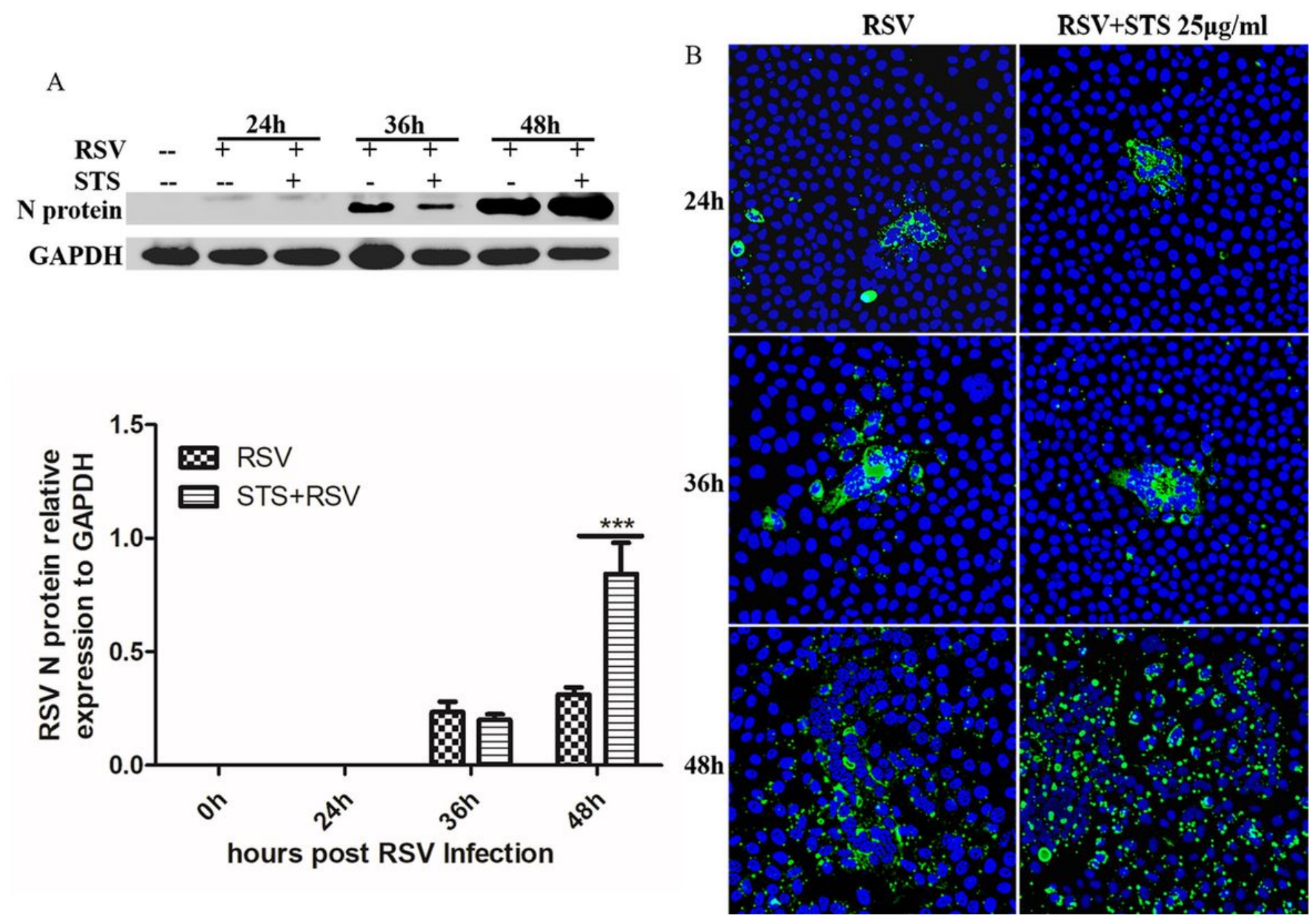

Figure 4

Kinetics of STS-regulated RSV replication in A549 cells. Western Blot and immunofluorescence staining were used to analyze the effect of $25 \mu \mathrm{g} / \mathrm{ml}$ STS on the expression of RSV N protein at 24-48 h post RSV infection. (A) RSV N protein examined by Western Blot.囚B囚RSV N protein examined by Immunofluorescence staining. bar $=75 \mu \mathrm{m}$. The results are representative of three independent experiments $(n=4)$, and all data are presented as the mean \pm SEM. $(* \star *) p<0.001$. 


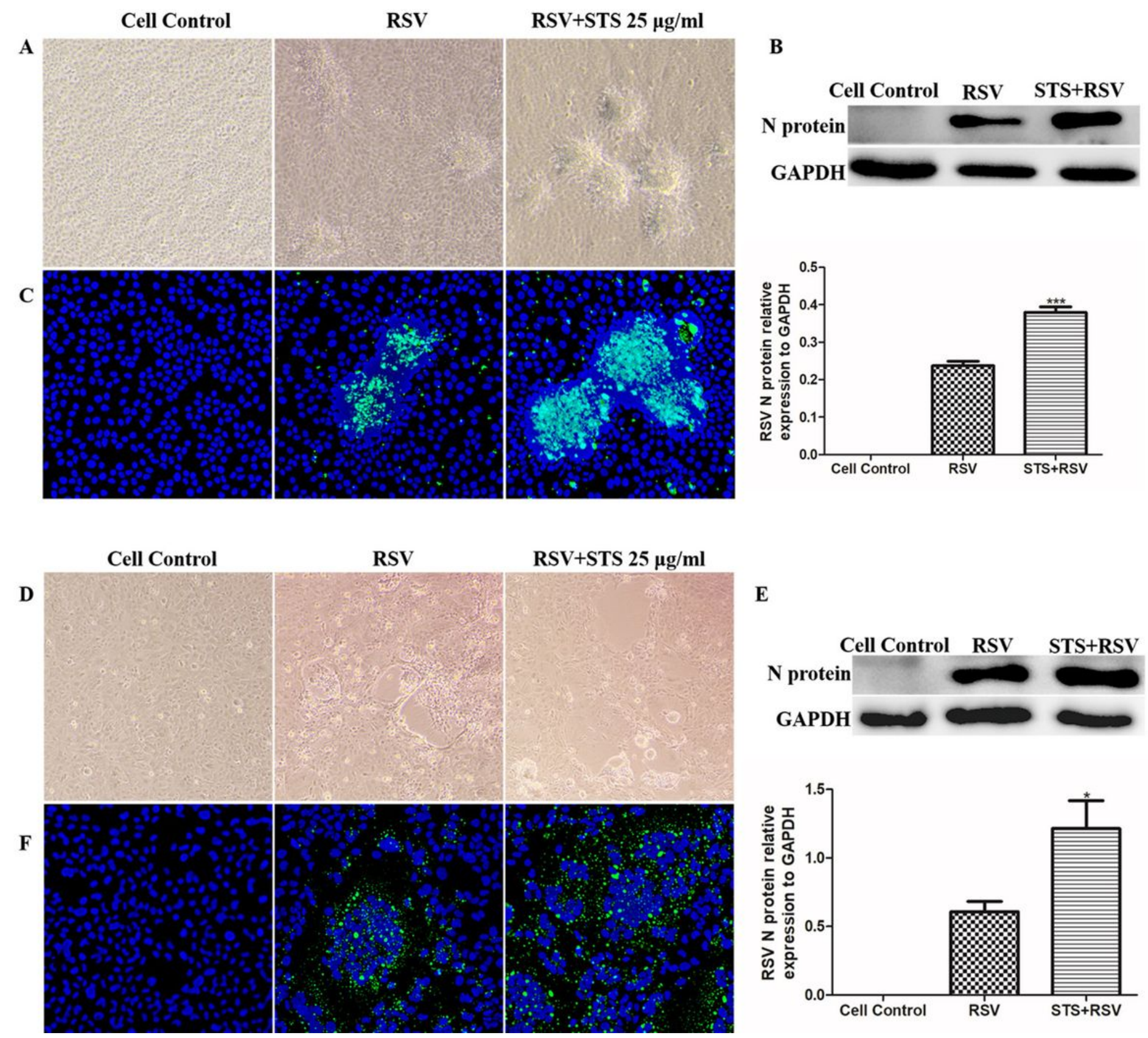

Figure 5

STS promotes RSV replication in different cell lines. 16HBE and BEAS-2B were used to investigate the effect of $25 \mu \mathrm{g} / \mathrm{ml}$ STS. CPE was observed and RSV N protein was detected by Western Blot and immunofluorescence staining at $60 \mathrm{~h}$ post RSV infection. (A) CPE in 16HBE. bar $=25 \mu \mathrm{m}$. (B) RSV N protein in $16 \mathrm{HBE}$ detected by Western Blot. (C) RSV N protein in $16 \mathrm{HBE}$ detected by Immunofluorescence staining. bar $=75 \mu \mathrm{m}$. (D) CPE in BEAS-2B. bar=25 $\mu \mathrm{m}$. (E) RSV N protein in BEAS-2B detected by Western Blot. (F) RSV N protein in BEAS-2B detected by Immunofluorescence staining. bar $=75 \mu \mathrm{m}$. The results are representative of three independent experiments $(n=4)$, and all data are presented as the mean \pm SEM. $\left(^{*}\right)$ $p<0.05$, and $(* * *) p<0.001$. 


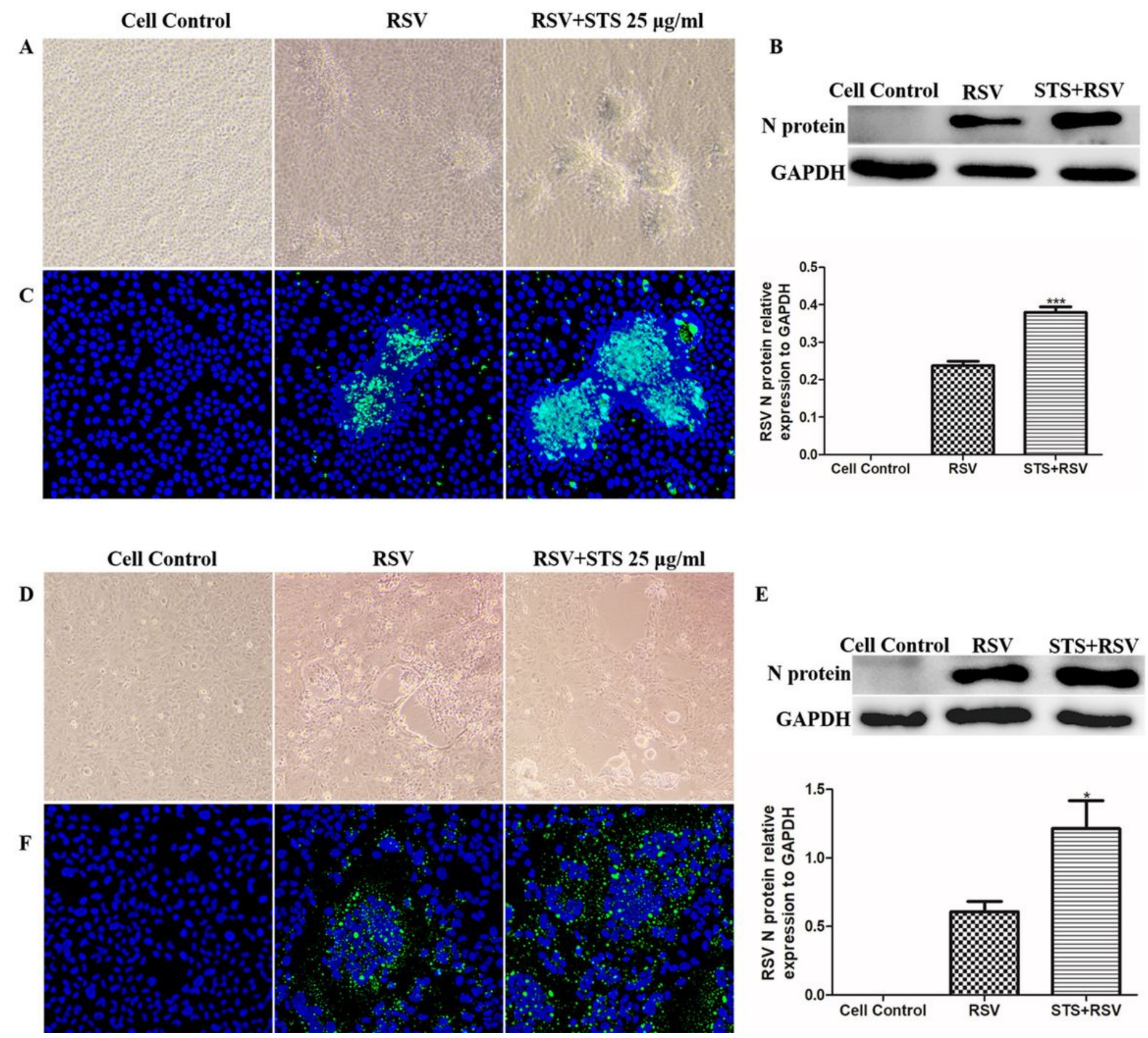

Figure 5

STS promotes RSV replication in different cell lines. 16HBE and BEAS-2B were used to investigate the effect of $25 \mu \mathrm{g} / \mathrm{ml}$ STS. CPE was observed and RSV N protein was detected by Western Blot and immunofluorescence staining at $60 \mathrm{~h}$ post RSV infection. (A) CPE in $16 \mathrm{HBE}$. bar $=25 \mu \mathrm{m}$. (B) RSV N protein in $16 \mathrm{HBE}$ detected by Western Blot. (C) RSV N protein in $16 \mathrm{HBE}$ detected by Immunofluorescence staining. bar $=75 \mu \mathrm{m}$. (D) CPE in BEAS-2B. bar=25 $\mu \mathrm{m}$. (E) RSV N protein in BEAS-2B detected by Western Blot. (F) RSV N protein in BEAS-2B detected by Immunofluorescence staining. bar $=75 \mu \mathrm{m}$. The results are representative of three independent experiments $(n=4)$, and all data are presented as the mean \pm SEM. $\left(^{*}\right)$ $p<0.05$, and $(* * *) p<0.001$. 


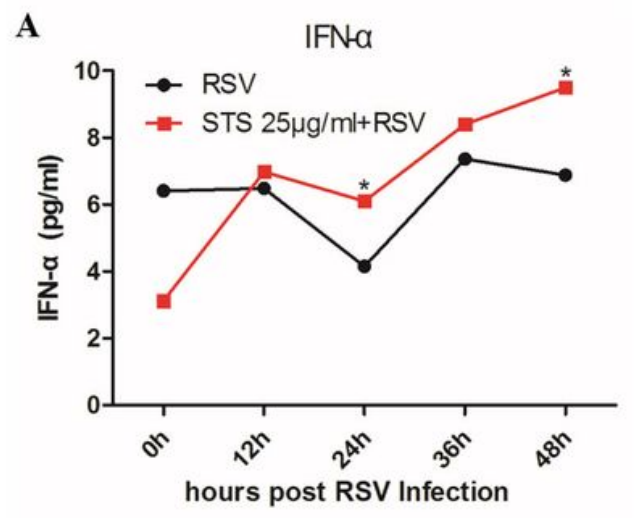

B
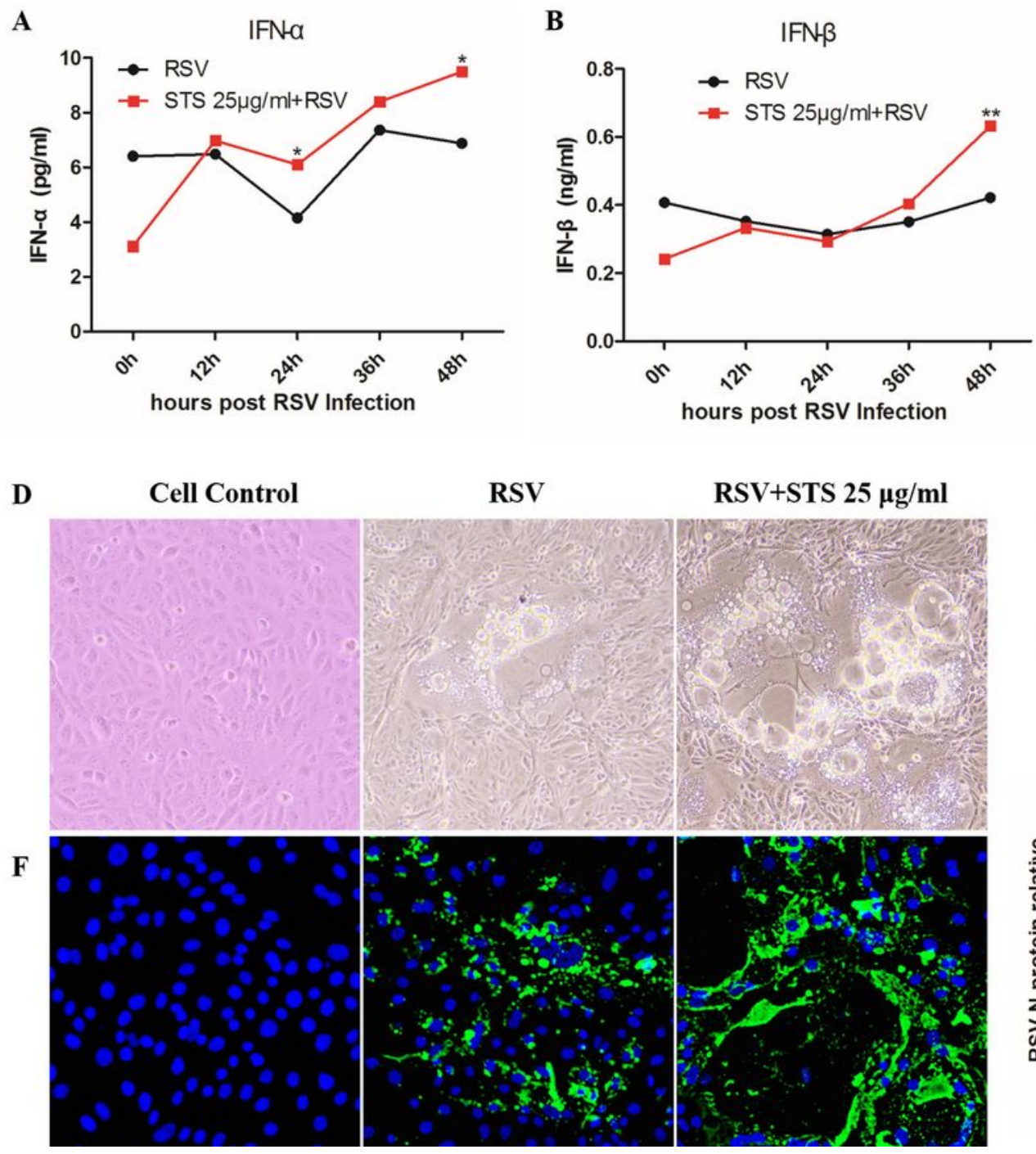

$\mathrm{RSV}+\mathrm{STS} 25 \mu \mathrm{g} / \mathrm{ml}$

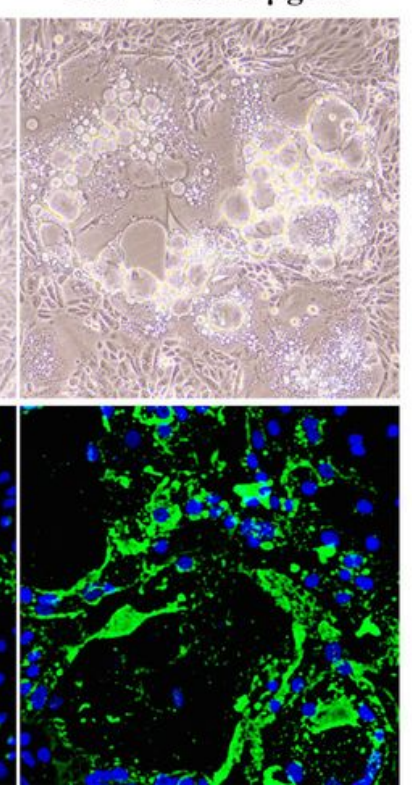

E

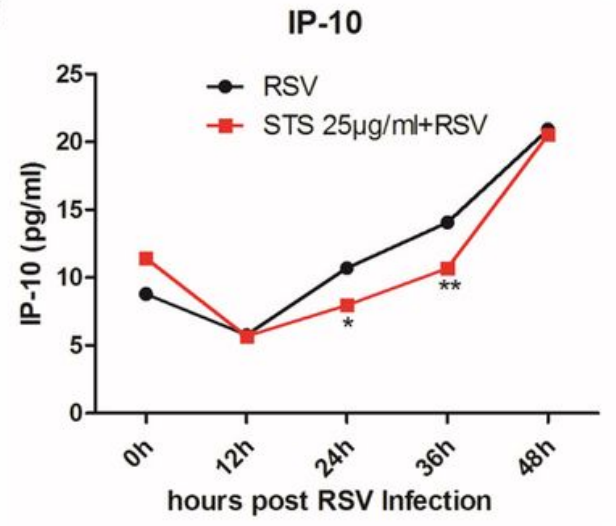

Cell Control RSV STS+RSV

$\mathrm{N}$ protein

GAPDH

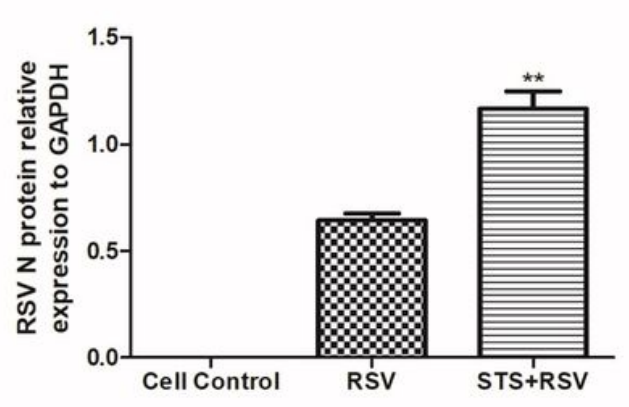

Figure 6

The effect of promotion RSV replication of STS is IFN-independent. IFN-aXIFN - $\beta$ and IP-10 from supernatants of $25 \mu \mathrm{g} / \mathrm{ml}$ STS treated cells (12-48h post RSV infection) were examined by ELISA and Vero cells were used to investigate the effect of $25 \mu \mathrm{g} / \mathrm{ml}$ STS. CPE was observed and RSV N protein was detected by Western Blot and immunofluorescence staining at 60h post RSV infection. (A) IFN-a. (B) IFNß. (C) IP-10. (D) CPE in Vero cells. bar=25 $\mu \mathrm{m}$. (E) RSV N protein in Vero cells detected by Western Blot. (F) RSV N protein in Vero cells detected by Immunofluorescence staining. bar $=75 \mu \mathrm{m}$. The results are representative of three independent experiments $(n=4)$, and all data are presented as the mean \pm SEM. $(*)$ $p<0.05$, and $(* *) p<0.01$. 


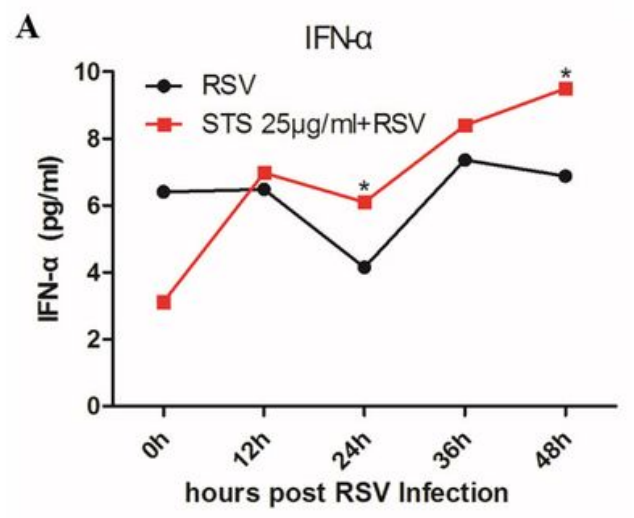

B
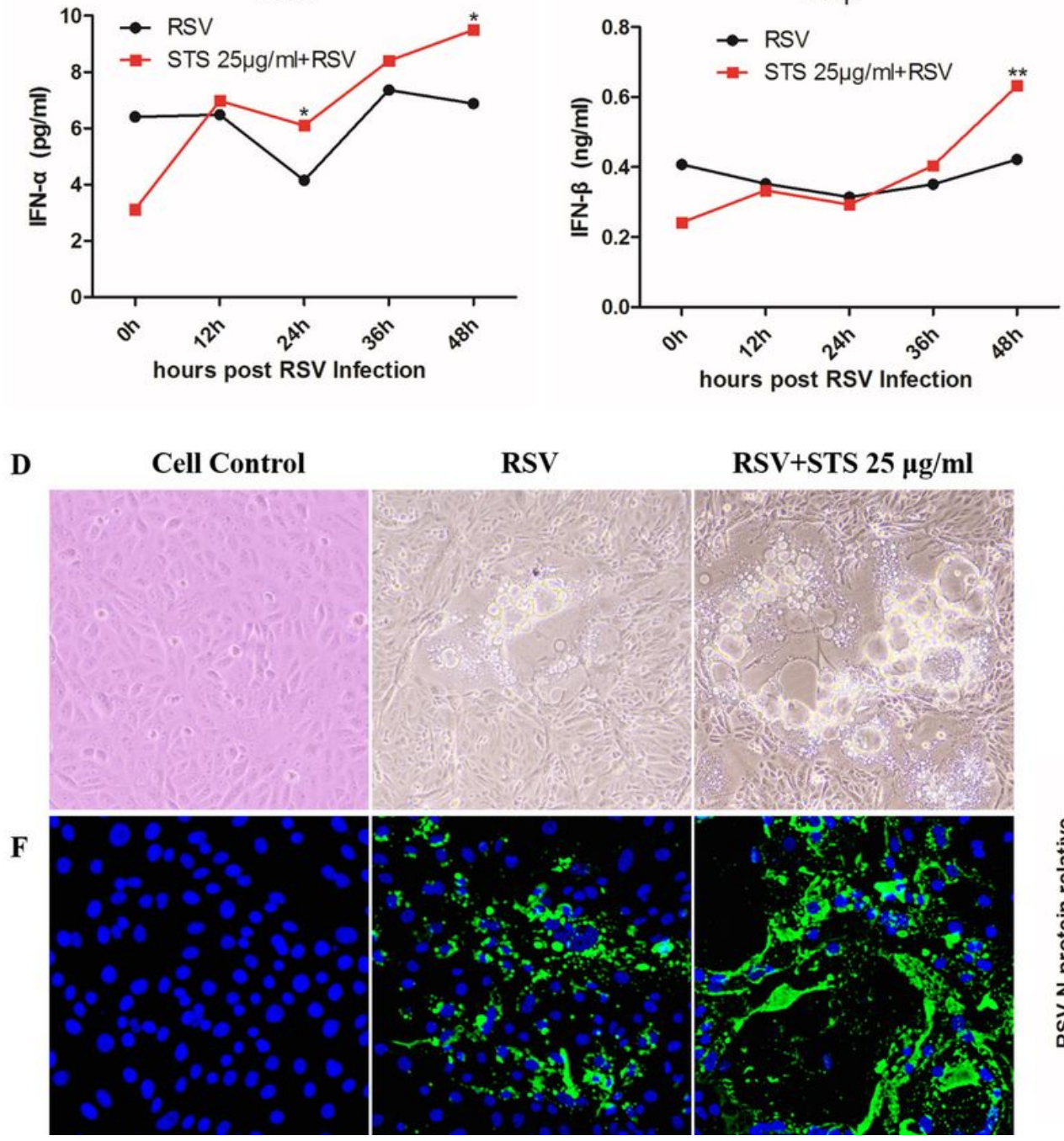

D
RSV

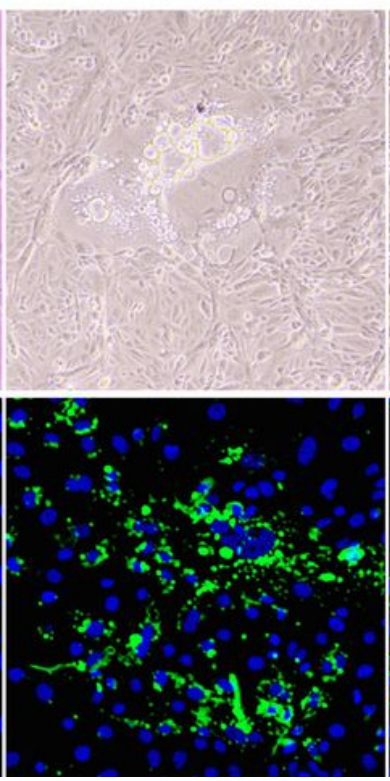

RSV+STS $25 \mu \mathrm{g} / \mathrm{ml}$

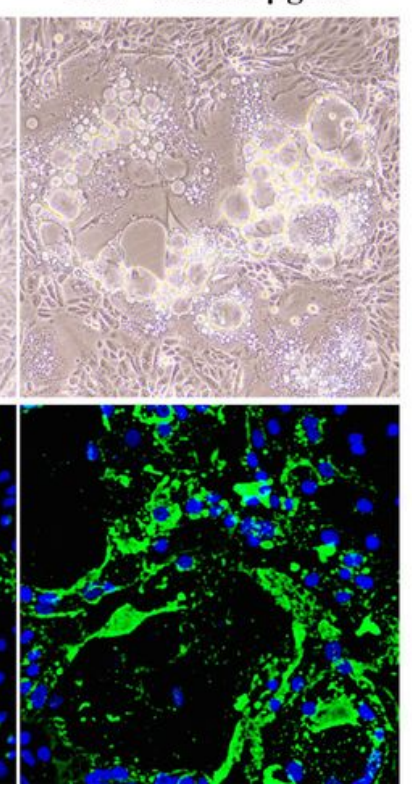

C IP-10

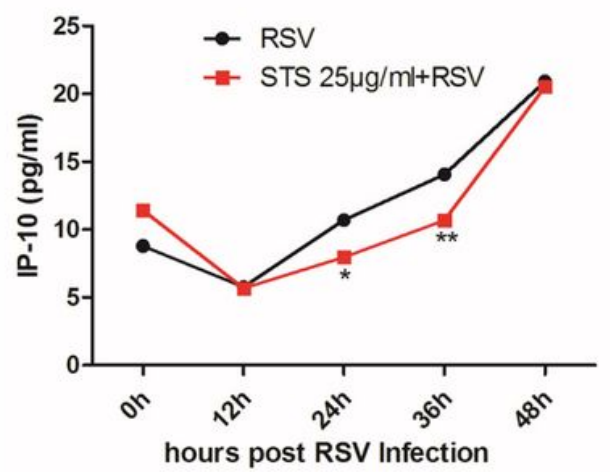

E

Cell Control RSV STS+RSV

$\mathrm{N}$ protein

GAPDH

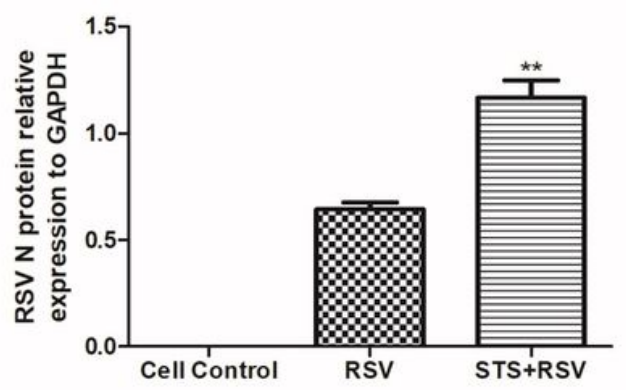

Figure 6

The effect of promotion RSV replication of STS is IFN-independent. IFN-a冈IFN - $\beta$ and IP-10 from supernatants of $25 \mu \mathrm{g} / \mathrm{ml}$ STS treated cells (12-48h post RSV infection) were examined by ELISA and Vero cells were used to investigate the effect of $25 \mu \mathrm{g} / \mathrm{ml} \mathrm{STS}$. CPE was observed and RSV N protein was detected by Western Blot and immunofluorescence staining at $60 \mathrm{~h}$ post RSV infection. (A) IFN-a. (B) IFN-

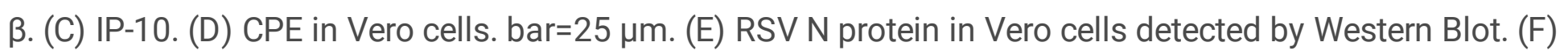
RSV N protein in Vero cells detected by Immunofluorescence staining. bar $=75 \mu \mathrm{m}$. The results are representative of three independent experiments $(n=4)$, and all data are presented as the mean \pm SEM. $(*)$ $p<0.05$, and $(* *) p<0.01$. 